
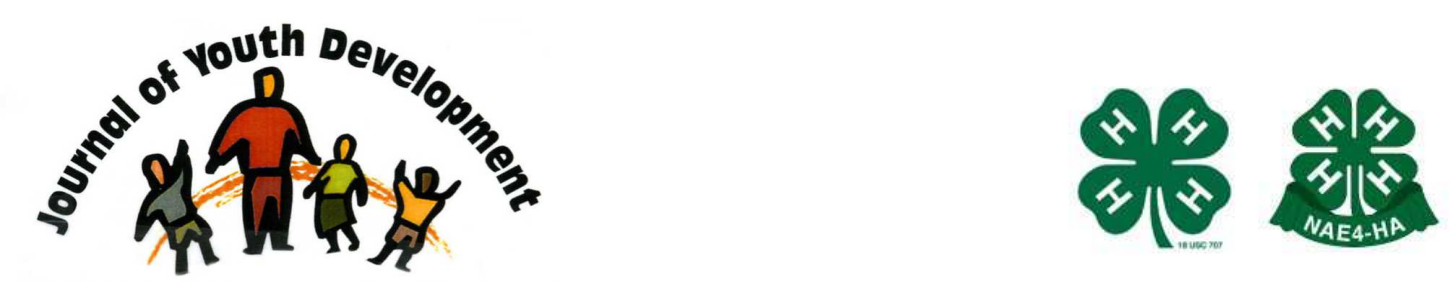

Bridging Research \& Practice

\title{
Resource Review: \\ The State of Girls: Unfinished Business
}

\author{
Patricia A. Dawson \\ Oregon State University \\ Pendleton, OR
}

patricia.dawson@oregonstate.edu 


\title{
JOURNAL OF YOUTH DEVELOPMENT \\ bridging research and practice

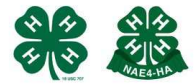

\section{Resource Review: The State of Girls: Unfinished Business}

Patricia A. Dawson

Oregon State University

\begin{abstract}
The State of Girls: Unfinished Business is an extensive report published by the Girl Scout Research Institute. The 156 page publication examines girls' health and well-being in the United States with a focus on key issues including health, educational achievement, demographic trends and safety. The report includes excellent charts, tables and diagrams and an appendix of state-level sources of data to support research findings. Youth professionals will appreciate this well documented, easy to comprehend resource as they engage in positive youth development programming.
\end{abstract}

\section{Review}

The Girl Scout Research Institute continues to develop excellent resources based on current national statistical indicators to examine key issues such as demographic trends of girls, health, safety and educational achievement. The State of Girls: Unfinished Business (Girl Scout Research Institute, 2013) provides a wealth of information regarding girls' health and well-being in the United States. The contents would be useful for youth professionals as well as policy makers and community leaders.

The 156 page publication is divided into nine major divisions:

1. The Changing Face of Girls - Growing racial/ethnic diversity, regional distribution, family structure and homelessness

2. Economic Well-Being and Employment Status - Poverty and Income

3. Physical Health and Safety - Health Insurance, Weight Conditions, Physical Activity, Substance Abuse and Safety

4. Emotional Health and Safety - Self-Esteem, Mental Health, Body Image, Relationships and Bullying

5. Education - Educational attainment and achievement, college enrollment, fields of study, financial literacy and women in STEM

6. Extracurricular and Out-of-School Activities - Childcare, Student Government, Clubs, Physical Activity, Religiosity, Evening Activities 
7. Girls' Leadership - How defined by girls, aspirations, leadership experiences and leadership skills.

8. Technology and Media Use - Access, Communicating through electronic media and impact of media use on health and well-being

9. What Was Learned - State of girls snapshot, data limitations, state-level data.

In addition to highlighting findings in the categories listed above, the report also cites the need for additional data to fully understand how girls are faring in the future examining the following issues: Bullying, Criminal Behavior, Disabilities, Exposure to Violence, Homelessness and Volunteering.

Detailed tables, charts and diagrams highlighting key findings are used throughout the report. Section summary pages and implications prove particularly helpful. An appendix at the conclusion of the report provides state-level sources of data supporting the document's chapter topics.

This resource is available at no charge as a download at www.girlscouts.org/research/pdf/sog full report.pdf

\section{References}

Girl Scout Research Institute, Schoenberg, J., Modi, K., Salmond, K., Mather, M., Jacobsen, L. (2013). The State of Girls: Unfinished Business. New York: Girl Scouts of the USA. accessed October 2014 www.girlscouts.org/research/pdf/sog full report.pdf .

(C) Copyright of Journal of Youth Development Bridging Research and Practice. Content may not be copied or emailed to multiple sites or posted to a listserv without copyright holder's express written permission. Contact Editor at: patricia.dawson@oregonstate.edu for details. However, users may print, download or email articles for individual use. ISSN 2325-4009 (Print); ISSN 2325-4017 (Online) 